\title{
Effect of Seasonal Temperature Variations on the Life Cycle Duration of Forensically Important Calliphorid Fly, Chrysomya saffranea (Bigot, 1877)
}

Fahd Mohammed A. Abd-Algalii ${ }^{12^{*}}$, Sureshchandra Popat Zambare ${ }^{1}$, Lubna A Khan ${ }^{1}$ and Kamlesh H Mali ${ }^{3}$

${ }^{1}$ Department of Zoology, Dr. Babasaheb Ambedkar Marathwada University, Aurangabad, India

${ }^{2}$ Department of Zoology, Faculty of Applied Sciences, Dhamar University, Dhamar, Yemen

${ }^{3}$ Department of Zoology, Adivasi Pragati Mandal Sanchalit Comrade Godavari Shamrao Parulekar Arts, Commerce and Science College, Maharashtra, India

*Corresponding author: Fahd M Abd Algalil, Department of Zoology, Dr. Babasaheb Ambedkar Marathwada University, Aurangabad, India, Tel: 00918806490584; Email: fahd_bamu@yahoo.com

Received date: November 11, 2016; Accepted date: January 09, 2017; Published date: January 14, 2017

Copyright: (c) 2017 Abd-Algalil FMA, et al. This is an open-access article distributed under the terms of the Creative Commons Attribution License, which permits unrestricted use, distribution, and reproduction in any medium, provided the original author and source are credited.

\section{Abstract}

The present study deals with the effects of variation in temperature and humidity on the different life cycle stages of Calliphoridae fly Chrysomya saffranea. In India for first time, Chrysomya saffranea was recorded apart from Australia as a native place of this fly.

In this study different life cycle stages of Chrysomya saffranea in different seasons were observed. In summer season when the average temperature ranged between $30.5^{\circ} \mathrm{C}$ and $33.2^{\circ} \mathrm{C}$ and the average humidity ranged between $12 \%$ to $19 \%$, life cycle duration was completed in $220 \mathrm{~h}$ (9.17 days) from the depositing of eggs up to the eclosion of adults. But in rainy season when the average temperature ranged between $25.6^{\circ} \mathrm{C}$ and $28.9^{\circ} \mathrm{C}$, and the average humidity ranged between $50 \%$ to $65 \%$, life cycle duration was completed in $259 \mathrm{~h}$ (10.79 days), while in winter season when the average temperature ranged between $17.8^{\circ} \mathrm{C}$ and $24.4^{\circ} \mathrm{C}$, and the average humidity ranged between $17 \%$ to $28 \%$, life cycle duration was completed in $341 \mathrm{~h}$ (14.21 days) from eggs up to emergence of the adults.

The temperature and humidity are the most important factors playing role in the larval development, decay and degradation of the cadavers. Therefore, the climatic fluctuations and environmental changes play an important role in the life cycle of Chrysomya saffranea. All these factors must be considered in the Post Mortem Interval determination.

Keywords: Forensic entomology; Postmortem interval; Calliphoridae fly; Chrysomya saffranea; Temperature; Humidity

\section{Introduction}

Forensic entomology is the use of insects and other arthropods as evidence in both civil and criminal investigations [1,2]. It deals with the insects associated with cadavers of human and animal remains to determine the Post-Mortem Interval (PMI) [3]. The wide range of this field can be divided into three subdivisions of urban, stored-product, and medico-legal forensic entomology [4]. Predominantly, blowfly larvae are the most common insects recovered from cadavers of humans; they can provide information on the conditions experienced by a body following death [5].

Chrysomya saffranea (Bigot, 1877), was recorded for first time in India [6], this fly also known as Steelblue fly or Australian blowfly [7]. In this study we used Chrysomya saffranea to study the effect of seasonal temperature on the life cycle duration and the time spent in the development of different stages of this fly and the impact of seasonal temperature on PMI determination. These blowflies of the genera Chrysomya (Diptera: Calliphoridae) are of considerable medical and sanitary importance since it is a myiasis producing agent in animals as well as humans. These flies are also important in forensic entomology since they can be used as biomarkers to estimate the Post Mortem Interval [8-10].
There are many factors which play an important role in the growth and development of arthropods, such as temperature, humidity, geographical location, seasons, decomposition time and habitat, which can affect the activity of the forensic flies and their life cycle [11-16]. Campobasso et al. [17] proved that the temperature and humidity are the most extrinsic factors playing an important role in the rate of postmortem decay and cadaver degradation.

Clark et al. [18] studied the insect activity at standard condition $\left(21^{\circ} \mathrm{C}\right.$ temperature and $30 \%$ humidity) and observed the insect activity within $96 \mathrm{~h}$ after death, while Campobasso et al. [17] reported that the oviposition can occur soon after death at favorable condition or at most within 2 days from the death.

Campobasso et al. [17] observed that the unfavorable temperature and humidity conditions can destroy the eggs easily, and found that in some cases the embryogenesis in eggs was slow down or stop showing a state of quiescence known as diapauses. However, the embryogenesis can resume normally once when the micro environmental condition become more favorable. Nielsen and Nielsen, [19] observed that the eggs of Chrysomya vicina (Diptera: Calliphoridae) did not hatch at temperature below $4^{\circ} \mathrm{C}$ while hatching of eggs and development of larvae occurred at $6^{\circ} \mathrm{C}$ to $7^{\circ} \mathrm{C}$.

Considerations of critical environmental factors affecting the rate of decomposition are very important during the crime investigations. These factors include location of the body, temperature, general 
Citation: Abd-Algalil FMA, Zambare SP, Khan LA, Mali KH (2017) Effect of Seasonal Temperature Variations on the Life Cycle Duration of Forensically Important Calliphorid Fly, Chrysomya saffranea (Bigot, 1877). J Forensic Res 8: 364. doi:10.4172/2157-7145.1000364

Page 2 of 6

climate, time of year, insect activity, animal activity in the area, and the amount of rainfall $[17,20,21]$.

To study the influence of fluctuating temperatures on insect development, one of five methods must be relied upon [22]. The first method involves transferring the insects from one temperature to another after a period of time has elapsed. The second is to record the temperatures of the natural environment by using a data logger or thermograph and the third method, similar to the first, is to transfer the insects to different temperatures according to a set pattern, The fourth method, which by no means emulates the natural environment, is to set up conditions where the insects develop at temperatures based on a gradient as a result of insect mobility. The fifth and final method is to set the desired conditions for the development and cycle the conditions every $24 \mathrm{~h} \mathrm{[22].}$

In this study we used the normal fluctuating temperatures at laboratory condition in different seasons and its effect on the life cycle duration, morphological parameters of different stages and the total life cycle duration from eggs depositing up to the adult eclosion.

\section{Materials and Methods}

Larvae of Calliphoridae species Chrysomya saffranea were collected from the dead body of cat at the garden of the Zoology Department at Dr Ambedkar Marathwada University Reserve (19² 522483 N, 75 192 123 E), Aurangabad City, Maharashtra State in India. Posteriorly, these larvae were reared in the laboratory by providing daily feed of buffalo`s fresh liver. Maggot culture was provided with fresh liver as a food till the prepupae stage. Prepupae were kept in $500 \mathrm{ml}$ beakers containing dry soil which is required for the pupation. Adult flies which emerged out from pupae were reared in rearing boxes of size 22 $\times 12 \times 10$ inches in dimensions (length $\times$ width $\times$ depth respectively). Purity of culture was maintained by separating the eggs immediately after depositing from the female. Larvae and adult were dissected from the pure culture with the help of stereo-zoom microscope (ERMA Optical works, Tokyo, No. 44883) and light microscope (Magnus
Trinocular Microscope MLX-DX, Olympus -India PVT. LTD. No. 4B525145) and identified according to the identification keys in $[7,6,23]$.

\section{Experimental Design}

In these experiments eggs were collected with the help of fine brush directly after laying and reared in summer, and rainy winter seasons at laboratory condition. After maintaining the pure culture of Chrysomya saffranea, to insure the same environmental condition at laboratory three experiments were conducted at the same time. Three groups of 80 larvae separately transferred into three glass beakers $500 \mathrm{ml}$ capacity; each group of larvae were daily fed on $50 \mathrm{gm}$ of buffalo's fresh liver till pupation. At the pupation time larvae were placed in small plastic tub 2 L capacity with $200 \mathrm{gm}$ of dried soil which is necessary for the pupation. Life cycle duration of different stages and the morphological parameters were recorded daily. The temperature and the relative humidity were also recorded by using Hygrothermometer clock. The experiment was repeated three times seasonably.

\section{Statistical Analysis}

Statistical analysis was performed using the excel sheet, data were analyzed statistically by using Two-ways analysis of variance (ANOVA) and significance level at $\mathrm{P} \leq 0.05$ was used.

\section{Results and Discussion}

\section{Life cycle in summer season}

The life cycle duration of Chrysomya saffranea has been studied when the average temperature ranged between $30.5^{\circ} \mathrm{C}$ and $33.2^{\circ} \mathrm{C}$ and the average humidity ranged between $12 \%$ to $19 \%$ (Table 1 ), PMI in h, different life cycle stages and morphological parameters were recorded as below:

\begin{tabular}{|c|c|c|c|c|c|c|}
\hline \multirow[b]{2}{*}{ Developmental stages } & \multicolumn{2}{|l|}{ Summer season } & \multicolumn{2}{|l|}{ Rainy season } & \multicolumn{2}{|l|}{ Winter season } \\
\hline & $\begin{array}{l}\text { Average Temperature } \\
\left({ }^{\circ} \mathrm{C}\right)\end{array}$ & $\begin{array}{l}\text { Average } \\
\text { Humidity (\%) }\end{array}$ & $\begin{array}{l}\text { Average Temperature } \\
\left({ }^{\circ} \mathrm{C}\right)\end{array}$ & $\begin{array}{l}\text { Average } \\
\text { Humidity (\%) }\end{array}$ & $\begin{array}{l}\text { Average Temperature } \\
\left({ }^{\circ} \mathrm{C}\right)\end{array}$ & $\begin{array}{l}\text { Average } \\
\text { Humidity (\%) }\end{array}$ \\
\hline Eggs & 30.5 & 19 & 28.9 & 65 & 24.4 & 28 \\
\hline 1st instar & 31.3 & 19 & 28.1 & 65 & 23.5 & 27 \\
\hline 2nd instar & 31.6 & 17 & 27.8 & 59 & 21.6 & 25 \\
\hline 3rd instar & 32.3 & 16 & 27.4 & 55 & 20.6 & 23 \\
\hline Prepupae & 32.7 & 16 & 27.1 & 55 & 20.6 & 21 \\
\hline pupae & 32.5 & 13 & 26.3 & 50 & 19.4 & 21 \\
\hline Adult & 33.2 & 12 & 25.6 & 51 & 17.8 & 17 \\
\hline
\end{tabular}

Table 1: Temperature and humidity variations in different seasons during the different developmental stages.

Eggs: The length, width and weight of the eggs of Chrysomya saffranea were $1.34 \mathrm{~mm}, 0.4 \mathrm{~mm}$, and $0.20 \mathrm{mg}$ respectively. The egg development took $19 \mathrm{~h}$ after which they hatched into 1st instar larvae.

Larvae (Maggot): The $1^{\text {st }}$ instar larva emerged from the eggs and took $20 \mathrm{~h}$ to develop. The average length, width and weight of the $1^{\text {st }}$ instar larvae were $4.5 \mathrm{~mm}, 1.6 \mathrm{~mm}$ and $8.3 \mathrm{mg}$ respectively. The $1^{\text {st }}$ instar larvae molted into $2^{\text {nd }}$ instar larvae which remained for $22 \mathrm{~h}$ from the $39^{\text {th }}$ up to $61^{\text {st }}$ hour of their life. The average length, width and weight of the $2^{\text {nd }}$ instar larvae were $6.7 \mathrm{~mm}, 2 \mathrm{~mm}$ and $25.5 \mathrm{mg}$ respectively. After $61 \mathrm{~h}$ of development the $2^{\text {nd }}$ instar larvae molted into $3^{\text {rd }}$ instar larvae which took up $24 \mathrm{~h}$ to develop. The average 
length, width and weight of $3^{\text {rd }}$ instar larvae were $11.2 \mathrm{~mm}, 4 \mathrm{~mm}$ and $56.1 \mathrm{mg}$ respectively.

Prepupae: Prepupae (post feeding stage) took $27 \mathrm{~h}$, and the size of the prepupae reduced. The average length, width and weight of prepupae were $9.3 \mathrm{~mm}, 3.6 \mathrm{~mm}$ and $44.6 \mathrm{mg}$ respectively.

Pupae: The pupal stage took up $108 \mathrm{~h}$. The average length, width and weight of pupae were $8.5 \mathrm{~mm}, 3.4 \mathrm{~mm}$ and $33.7 \mathrm{mg}$ respectively.

Adult: Adult flies emerged out from the pupae after $220 \mathrm{~h}$ of development. That means that the life cycle of Chrysomya saffranea in summer was completed in $220 \mathrm{~h}$ from the egg-laying stage up to the adult eclosion. The average length, width and weight of adult were 8 $\mathrm{mm}, 3 \mathrm{~mm}$ and $29.5 \mathrm{mg}$ respectively. PMI in h and morphological parameters of the different stages in different seasons are shown in Tables 2-5.

\section{Life cycle in rainy season}

Life cycle duration of Chrysomya saffranea has been studied in rainy season when the average temperature and relative humidity were ranged between $25.6^{\circ} \mathrm{C}$ to $28.9^{\circ} \mathrm{C}$, and $50 \%$ to $65 \%$ respectively (Table $1)$, different life cycle stages and morphological parameters were recorded as below:

Eggs: The average length, width and weight of the eggs were 1.46 $\mathrm{mm}, 0.4 \mathrm{~mm}$ and $0.21 \mathrm{mg}$ respectively. The eggs hatched into $1^{\text {st }}$ instar larvae after $22 \mathrm{~h}$ from the depositing.

Larvae (Maggots): The $1^{\text {st }}$ instar larval development took $22 \mathrm{~h}$, and the average length, width and weight of $1^{\text {st }}$ instar was $5.5 \mathrm{~mm}, 1.9 \mathrm{~mm}$ and $12.6 \mathrm{mg}$ respectively. The $1^{\text {st }}$ instar larvae took $28 \mathrm{~h}$ to molt into $2^{\text {nd }}$ instar larvae. At $72 \mathrm{hrs}$ of development, the average length, width and weight of the $2^{\text {nd }}$ instar larvae was $9.4 \mathrm{~mm}, 2.5 \mathrm{~mm}$ and $30.2 \mathrm{mg}$ respectively. The $3^{\text {rd }}$ instar larvae development started from $72 \mathrm{~h}$ after eggs depositing and continued up to $102 \mathrm{~h}$, and the average length, width and weight of the $3^{\text {rd }}$ instar larvae were $14.2 \mathrm{~mm}, 4.2 \mathrm{~mm}$ and $68.1 \mathrm{mg}$ respectively.

Prepupae: The developmental duration of prepupae started from $102 \mathrm{~h}$ to $130 \mathrm{~h}$. And the average length, width and weight were 10.5 $\mathrm{mm}, 4 \mathrm{~mm}$ and $47.5 \mathrm{mg}$ respectively.

Pupae: The pupal stage development took $129 \mathrm{~h}$. The average length, width and weight of the pupae were $9.4 \mathrm{~mm}, 3.6 \mathrm{~mm}$ and $38.2 \mathrm{mg}$ respectively.

Adult: The adult emerged out from the pupae after $259 \mathrm{~h}$ of development. That means the life cycle duration of Chrysomya saffranea in rainy season was completed in $259 \mathrm{~h}$, and the average length, width and weight of the adult were $9 \mathrm{~mm} ; 3.3 \mathrm{~mm}$ and $32.3 \mathrm{mg}$ respectively. PMI in $\mathrm{h}$ and morphological parameters of the different stages are shown in Tables 2-5.

\section{Life cycle in winter season}

Life cycle duration of Chrysomya saffranea has been studied in winter season when the average temperature ranged between $17.8^{\circ} \mathrm{C}$ and $24.4^{\circ} \mathrm{C}$, and $17 \%$ to $28 \%$ average humidity (Table 1), different life cycle stages and morphological parameters were recorded as below:

Eggs: After depositing, the eggs were immediately collected; the average length width and weight of the eggs were $1.13 \mathrm{~mm}, 0.4 \mathrm{~mm}$ and $0.20 \mathrm{mg}$ respectively. After $27 \mathrm{~h}$ of development the eggs hatched into 1st instar larvae.
Larvae (Maggot): The $1^{\text {st }}$ instar larvae took $30 \mathrm{~h}$ to develop, the average length, width and weight of the $1^{\text {st }}$ instar larvae were $4 \mathrm{~mm}, 1.3$ $\mathrm{mm}$ and $7.6 \mathrm{mg}$ respectively. The duration spent for $2^{\text {nd }}$ instar to reach the $3^{\text {rd }}$ instar was $30 \mathrm{~h}$, and the average length, width and weight of the $2^{\text {nd }}$ instar larvae were $6 \mathrm{~mm}, 1.8 \mathrm{~mm}$ and $20.1 \mathrm{mg}$ respectively. The $3^{\text {rd }}$ instar larvae took $42 \mathrm{~h}$, and the average length, width and weight of $3^{\text {rd }}$ instar larvae were $9.2 \mathrm{~mm}, 3.4 \mathrm{~mm}$ and $42.2 \mathrm{mg}$ respectively.

Prepupae: This non-feeding stage took up $40 \mathrm{~h}$ to develop from 129 $\mathrm{h}$ up to $169 \mathrm{~h}$. The average length, width and weight of prepupae were $8.7 \mathrm{~mm}, 3.2 \mathrm{~mm}$ and $32.2 \mathrm{mg}$ respectively.

Pupae: The pupal stage took up $172 \mathrm{~h}$ to develop. The average length, width and weight of the pupae were $8 \mathrm{~mm}, 3 \mathrm{~mm} 30.4 \mathrm{mg}$ respectively.

Adult: Adult emerged out from the pupae after $341 \mathrm{~h}$ from the depositing of eggs. That means life cycle of Chrysomya saffranea in winter was completed in $341 \mathrm{~h}$. The average length, width and weight of adult were $7.4 \mathrm{~mm}, 2.7 \mathrm{~mm}$ and $24.3 \mathrm{mg}$ respectively. PMI in hour and morphological parameters of the different stages in different seasons are shown in Tables 2-5.

The summaries of PMI duration in different seasons are shown in Figure 1.1. Morphological parameters of different developmental stages of Chrysomya saffranea in different seasons are showed in Figures 1.2 to 1.4 .

In summer, the total developmental time spent in the feeding stages was $66 \mathrm{~h}$ (2.75 days) and in rainy season $80 \mathrm{~h}$ (3.33 days) indicating a delay of more than half a day from the time spent in summer, while in winter the time spent in the feeding stages was $102 \mathrm{~h}$ ( 4.25 days) indicating a delay of about one day compared to the rainy season and two days compared to the time spent in summer. The developmental time spent in the post feeding and the pupal stages in summer was 135 $\mathrm{h}$ (5.63 days) and in rainy season it was $157 \mathrm{~h}$ (6.54 days) which showed a delay of about one day from the time spent in summer, while in winter $212 \mathrm{~h}$ (8.83 days) ware spent, indicating a delay of about three days from the time spent in summer and about two days from the time spent in the rainy season.

The total life cycle duration of Chrysomya saffranea in summer was completed in $220 \mathrm{hrs}$ (9.17 days) when the average temperature ranged from $30.5^{\circ} \mathrm{C}$ to $33.2^{\circ} \mathrm{C}$ and the average humidity ranged from $12 \%$ to $19 \%$, but in rainy season it was completed in $259 \mathrm{~h}$ (10.79 days) when the average temperature ranged from $25.6^{\circ} \mathrm{C}$ to $28.9^{\circ} \mathrm{C}$ and the average humidity ranged from $50 \%$ to $65 \%$, while in winter it was completed in $341 \mathrm{~h}$ (14.21 days) when the average temperature and humidity ranged from $17.8^{\circ} \mathrm{C}$ to $24.4^{\circ} \mathrm{C}$ and $17 \%$ to $28 \%$ respectively. Likewise, the shortest life cycle duration was recorded in summer, then followed by the rainy season and the longest life cycle duration was in winter season.

This result supported the previous study on Lucilia sericata (Diptera: Calliphoridae), when it was reared in different temperatures of $15^{\circ} \mathrm{C}, 17^{\circ} \mathrm{C}, 19^{\circ} \mathrm{C}, 20^{\circ} \mathrm{C}, 21^{\circ} \mathrm{C}, 22^{\circ} \mathrm{C}, 25^{\circ} \mathrm{C}, 28^{\circ} \mathrm{C}, 30^{\circ} \mathrm{C}$ and $34^{\circ} \mathrm{C}$, and the shortest life cycle duration of $259 \mathrm{~h}$ was observed in $34^{\circ} \mathrm{C}$, while the longest duration of $842 \mathrm{~h}$ was observed in $17^{\circ} \mathrm{C}$ but in $15^{\circ} \mathrm{C}$, the period recorded up to post feeding was $340 \mathrm{~h}$ and there are no records of emergence of the adult in this lowest temperature [24].

Similarly in the previous study on the developmental duration of Chrysomya megacephala (Diptera: Calliphoridae), in rainy season and low constant temperature of $10^{\circ} \mathrm{C}$ and humidity $19 \%$, reported that the total life cycle duration in rainy season was completed in $265 \mathrm{~h} \pm 2 \mathrm{~h}$ 
Citation: Abd-Algalil FMA, Zambare SP, Khan LA, Mali KH (2017) Effect of Seasonal Temperature Variations on the Life Cycle Duration of Forensically Important Calliphorid Fly, Chrysomya saffranea (Bigot, 1877). J Forensic Res 8: 364. doi:10.4172/2157-7145.1000364

Page 4 of 6

(11.04 days \pm 0.08 days) when the temperature ranged between $26^{\circ} \mathrm{C}$ and $29^{\circ} \mathrm{C}$ and humidity ranged between $35 \%$ and $50 \%$, while in the low constant temperature $10^{\circ} \mathrm{C} \pm 0.5^{\circ} \mathrm{C}$ the life cycle was completed in 609 $\mathrm{h} \pm 4 \mathrm{~h}$ ( 25.38 days \pm 0.16 days $)$ indicating a delay in the life cycle by 14.37 days \pm 0.13 days [25].

These results are in agreement with the data obtained in the present study. Similarly our current results are in agreement with another study on the effect of different temperature and humidity on the life cycle duration and morphological parameters of Chrysomya rufifacies
(Diptera: Calliphoridae) in different seasons, it was reported that the life cycle of Chrysomya rufifacies in summer was completed in $241 \pm$ $2.17 \mathrm{~h}$ (10.04 days \pm 0.12 days) when the temperature ranged between $30.1^{\circ} \mathrm{C}$ and $37.2^{\circ} \mathrm{C}$, but in the rainy season it was completed in $275 \mathrm{~h} \pm$ $2.27 \mathrm{~h}$ (11.46 days \pm 0.45 days), when the temperature ranged between $26.2^{\circ} \mathrm{C}$ and $30.1^{\circ} \mathrm{C}$, while in winter the life cycle was completed in 318 $\mathrm{h} \pm 2.45 \mathrm{~h}$ ( 13.25 days \pm 0.25 days $)$ when the temperatures ranged between $26.4^{\circ} \mathrm{C}$ and $18.2^{\circ} \mathrm{C}$ respectively [26].
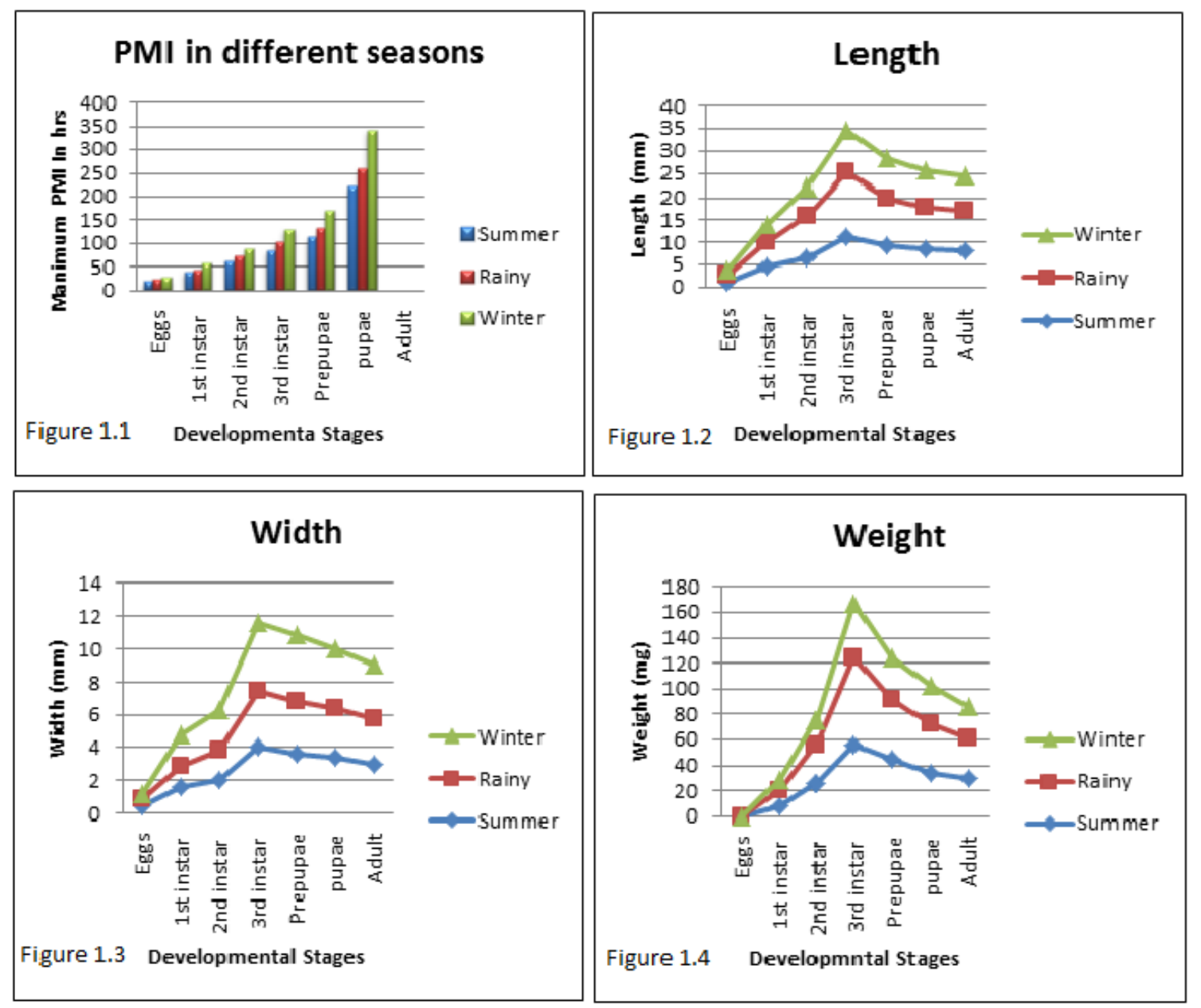

Figure 1: PMI in h and morphological parameter of different developmental stages in different seasons. 1.1: PMI in h in different seasons; 1.2: Length of developed stages in different seasons; 1.3: Width of developed stages in different seasons; 1.4: Weight of developed stages in different seasons.

Similar study on the developmental time of forensically important blow fly species (Diptera: Calliphoridae) Phormia regina (Meigen, 1826) at different constant minimum and maximum threshold temperatures $\left(8^{\circ} \mathrm{C}\right.$ to $\left.32^{\circ} \mathrm{C}\right)$ reported that no development occurred at $12^{\circ} \mathrm{C}$ and below but in $14^{\circ} \mathrm{C}$ the total life cycle was of 45 days and at $26^{\circ} \mathrm{C}$ the total life duration was 13 days, while at $32^{\circ} \mathrm{C}$ the total life cycle was of 11.3 days [27].

Warren and Anderson, [28] compared the immature development of (Diptera: Calliphoridae) Protophormia terraenovae (Robineau-
Desvoidy, 1830) at fluctuating temperatures of $4-28$ and $9^{\circ} \mathrm{C}$ to $23^{\circ} \mathrm{C}$ and at their mean constant temperature $16^{\circ} \mathrm{C}$, they reported that the development was fastest at the greater fluctuation and slowest at the constant temperature and showed similar percentages of development time in each stage. They conclude that the fluctuations above the mean enhance the developmental rate relatively more than temperatures below the mean can reduce the developmental rate.

Another study on the developmental rate of forensically important (Diptera: Calliphoridae) species Chrysomya albiceps at different 
Citation: Abd-Algalil FMA, Zambare SP, Khan LA, Mali KH (2017) Effect of Seasonal Temperature Variations on the Life Cycle Duration of Forensically Important Calliphorid Fly, Chrysomya saffranea (Bigot, 1877). J Forensic Res 8: 364. doi:10.4172/2157-7145.1000364

Page 5 of 6

constant temperature $15^{\circ} \mathrm{C}, 20^{\circ} \mathrm{C}, 25^{\circ} \mathrm{C}, 30^{\circ} \mathrm{C}$ and $35^{\circ} \mathrm{C}$ reported that at $15^{\circ} \mathrm{C}$ all pupae failed to develop to adult but the total life cycle at $20^{\circ} \mathrm{C}$ was about 18.5 days, while at $25^{\circ} \mathrm{C}, 30^{\circ} \mathrm{C}$ and $35^{\circ} \mathrm{C}$ the total life cycle duration were 14.1 days, 9.8 days and 9.2 days respectively, These results support that the shortest life cycle was at high temperature and longer duration was at lower temperature [29].

\begin{tabular}{|c|c|c|c|c|}
\hline \multirow[b]{2}{*}{ Stages } & \multirow{2}{*}{$\begin{array}{l}\text { Developmental } \\
\text { stages }\end{array}$} & \multicolumn{3}{|c|}{$\begin{array}{l}\text { PMI in Hours in different } \\
\text { seasons }\end{array}$} \\
\hline & & Summer & Rainy & Winter \\
\hline \multirow{7}{*}{$P$-value $=8.10 \mathrm{E}-06$} & Eggs & 19 & 22 & 27 \\
\hline & $1^{\text {st }}$ instar & 39 & 44 & 57 \\
\hline & $2^{\text {nd }}$ instar & 61 & 72 & 87 \\
\hline & $3^{\text {rd }}$ instar & 85 & 102 & 129 \\
\hline & Prepupae & 112 & 130 & 169 \\
\hline & pupae & 220 & 259 & 341 \\
\hline & Adult & & & \\
\hline & Seasons & \multicolumn{3}{|l|}{$P$-value $=$} \\
\hline
\end{tabular}

Table 2: PMI in hours of different developmental stages in different Seasons with the $\mathrm{P}$-value at level $\mathrm{P} \leq 0.05$.

\begin{tabular}{|c|c|c|c|c|}
\hline \multirow[b]{2}{*}{ Stages } & \multirow{2}{*}{$\begin{array}{l}\text { Developmental } \\
\text { stages }\end{array}$} & \multicolumn{3}{|c|}{ Length $(\mathrm{mm})$ in different seasons } \\
\hline & & Summer & Rainy & Winter \\
\hline \multirow{7}{*}{$\begin{array}{l}P- \\
\text { value }=1.42 E-05\end{array}$} & Eggs & $\begin{array}{l}1.34 \quad \pm \\
0.05\end{array}$ & $\begin{array}{l}1.46 \quad \pm \\
0.05\end{array}$ & $\begin{array}{l}1.13 \quad \pm \\
0.02\end{array}$ \\
\hline & 1st instar & $4.5 \pm 0.08$ & $5.5 \pm 0.16$ & $4 \pm 0.26$ \\
\hline & 2nd instar & $6.7 \pm 0.22$ & $9.4 \pm 0.02$ & $6 \pm 0.13$ \\
\hline & 3rd instar & $\begin{array}{l}11.2 \\
0.24\end{array}$ & $\begin{array}{l}14.2 \quad \pm \\
0.23\end{array}$ & $9.2 \pm 0.26$ \\
\hline & Prepupae & $9.3 \pm 0.11$ & $\begin{array}{l}10.5 \quad \pm \\
0.21\end{array}$ & $8.7 \pm 0.17$ \\
\hline & pupae & $8.5 \pm 0.04$ & $9.4 \pm 0.11$ & $8 \pm 0.12$ \\
\hline & Adult & $8 \pm 0.13$ & $9 \pm 0.15$ & $7.4 \pm 0.22$ \\
\hline & Seasons & \multicolumn{3}{|c|}{ P-value $=0.0006$} \\
\hline
\end{tabular}

Table 3: Length of different developmental stages in different Seasons with the $\mathrm{P}$-value at level $\mathrm{P} \leq 0.05$.

Higher temperatures generally support egg hatching and accelerate maturation of larvae which can double their size in few $\mathrm{h}$ and reduce the development time of Diptera. Once the Calliphoridae larvae have reached maximum length at the peak of feeding, they tend to decline progressively to about $75 \%$ of the length in the Calliphorid pre-adult cycle spent in post feeding and pupation $[30,17]$.

The data obtained on PMI, length, width and weight of (Diptera: Calliphoridae) Chrysomya saffranea in the present study during three seasons (summer, Rainy and winter) were statistically analyzed for analysis of variance (ANOVA) and the P-value obtained are shown in Tables 2-5.

\begin{tabular}{|c|c|c|c|c|}
\hline \multirow[b]{2}{*}{ Stages } & \multirow{2}{*}{$\begin{array}{l}\text { Developmental } \\
\text { stages }\end{array}$} & \multicolumn{3}{|c|}{ Width $(\mathrm{mm})$ in different Seasons } \\
\hline & & Summer & Rainy & Winter \\
\hline \multirow{8}{*}{$P$-value $=8.13 \mathrm{E}-11$} & Eggs & $\begin{array}{ll}0.4 & \pm \\
0.06 & \end{array}$ & $0.4 \pm 0.06$ & $0.4 \pm 0.06$ \\
\hline & 1st instar & $\begin{array}{ll}1.6 & \pm \\
0.24 & \end{array}$ & $1.9 \pm 0.24$ & $1.3 \pm 0.14$ \\
\hline & 2nd instar & $2 \pm 0.11$ & $2.5 \pm 0.11$ & $1.8 \pm 0.24$ \\
\hline & 3rd instar & $4 \pm 0.24$ & $4.2 \pm 0.14$ & $3.4 \pm 0.14$ \\
\hline & Prepupae & $\begin{array}{ll}3.6 & \pm \\
0.22 & \end{array}$ & $4 \pm 0.22$ & $3.2 \pm 0.14$ \\
\hline & pupae & $\begin{array}{ll}3.4 & \pm \\
0.33 & \end{array}$ & $3.6 \pm 0.23$ & $3 \pm 0.21$ \\
\hline & Adult & $3 \pm 0.16$ & $3.3 \pm 0.24$ & $2.7 \pm 0.13$ \\
\hline & Seasons & \multicolumn{3}{|c|}{$P$-value $=2.42 \mathrm{E}-07$} \\
\hline
\end{tabular}

Table 4: Width of different developmental stages in different Seasons with the $\mathrm{P}$-value at level $\mathrm{P} \leq 0.05$.

\begin{tabular}{|c|c|c|c|c|}
\hline \multirow{2}{*}{ Stages } & \multirow{2}{*}{$\begin{array}{l}\text { Developmental } \\
\text { stages }\end{array}$} & \multicolumn{3}{|c|}{ Weight $(\mathrm{mg})$ in different Seasons } \\
\hline & & Summer & Rainy & Winter \\
\hline \multirow{8}{*}{ P-value $=1.59 \mathrm{E}-06$} & Eggs & $\begin{array}{ll}0.20 & \pm \\
0.03 & \end{array}$ & $\begin{array}{l}0.21 \quad \pm \\
0.03\end{array}$ & $\begin{array}{l}0.20 \\
0.03\end{array}$ \\
\hline & 1st instar & $8.3 \pm 0.64$ & $\begin{array}{l}12.6 \quad \pm \\
0.14\end{array}$ & $7.6 \pm 0.23$ \\
\hline & 2nd instar & $\begin{array}{ll}25.5 & \pm \\
0.02 & \end{array}$ & $\begin{array}{l}30.2 \quad \pm \\
0.02\end{array}$ & $\begin{array}{l}20.1 \\
0.12\end{array}$ \\
\hline & 3rd instar & $\begin{array}{ll}56.1 & \pm \\
0.33 & \end{array}$ & $\begin{array}{l}68.1 \quad \pm \\
0.31\end{array}$ & $\begin{array}{l}42.2 \\
0.22\end{array}$ \\
\hline & Prepupae & $\begin{array}{ll}44.6 & \pm \\
0.21 & \end{array}$ & $\begin{array}{l}47.5 \\
0.16\end{array}$ & $\begin{array}{ll}32.2 & \pm \\
0.16 & \end{array}$ \\
\hline & pupae & $\begin{array}{ll}33.7 & \pm \\
0.34 & \end{array}$ & $\begin{array}{l}38.2 \quad \pm \\
0.14\end{array}$ & $\begin{array}{l}30.4 \\
0.24\end{array}$ \\
\hline & Adult & $\begin{array}{l}29.5 \\
0.06\end{array}$ & $\begin{array}{l}32.3 \\
0.16\end{array}$ & $\begin{array}{l}24.3 \\
0.06\end{array}$ \\
\hline & Seasons & \multicolumn{3}{|c|}{$P$-value $=0.0014$} \\
\hline
\end{tabular}

Table 5: Weight of different developmental stages in different Seasons with the $\mathrm{P}$-value at level $\mathrm{P} \leq 0.05$.

On the basis of the P- values, it can be stated that there was significant variation in PMI, length, width and weight of Chrysomya saffranea (Diptera: Calliphoridae) species among the various growth stage as well as among the three seasons.

Thus, it can be concluded that different growth stages as well as different seasons were responsible for the variation in the morphological parameter of this species. The values obtained during ANOVA analysis clearly indicated significant variation among duration of PMI of different stages, length, width and weight of all the three species. 
Citation: Abd-Algalil FMA, Zambare SP, Khan LA, Mali KH (2017) Effect of Seasonal Temperature Variations on the Life Cycle Duration of Forensically Important Calliphorid Fly, Chrysomya saffranea (Bigot, 1877). J Forensic Res 8: 364. doi:10.4172/2157-7145.1000364

Page 6 of 6

\section{Conclusion}

From the previous studies and our recent study we can conclude that the longest life cycle duration was in winter when the temperature was low followed by rainy season while the shortest period was observed in summer, indicating that the warmer temperature accelerates the development and growth rate and shorts the life cycle, while the cooler temperature slows-down the growth rate and extends the life cycle duration of different stages. And the analyzed data have been showed a significant variation in the life cycle durations and in the morphological parameters of the different stages in the different seasons.

\section{Acknowledgement}

The authors would like to thank the financial support provided through the higher studies and scientific research, Thamar University, Yemen and they want to express their thankful to the Department of Zoology at Dr. Babasaheb Ambedkar Marathwada University, Aurangabad, India for providing the laboratory facility to carry our work in the forensic entomology laboratory.

\section{References}

1. Smith KGV (1986) A manual of forensic entomology. The British Museum (Natural History) and Cornell University Press, London, UK.

2. Williams KA, Villet MH (2006) A history of southern African researchogy. South African Journal of Science 102: 59-65

3. Byrd JH, Castner JL (2001) Insects of forensic importance, Forensic entomology: the utility of arthropods in legal investigations. CRC, Boca Raton, FL pp: 43-79.

4. Archer M (2007) Forensic entomology. Australian Police J 61: 66-70.

5. Donovan SE, Hall MJR, Turner BD, Moncrieff CB (2006) Larval growth rates of the blowfly, Calliphora vicina, over a range of temperatures. Med Vet Entomol 20: 106-114.

6. Abd-AlGalil FMA, Zambare SP, Mashaly AMA (2016) First record of Chrysomya saffranea (Diptera: Calliphoridae) of forensic importance in India. Tropical Biomedicine 33: 102-108.

7. Spradbery JP (2002) A manual for the diagnosis of screw-worm fly, Department Agriculture, Fisheries and Forestry, Canberra, Australia.

8. Gomes L, Gomes G, Oliveira HG, Sanches MR, Von Zuben CJ (2006) Influence of photoperiod on body weight and depth of burrowing in larvae of Chrysomya megacephala (Fabricius)(Diptera, Calliphoridae) and implications for forensic entomology. Rev Bras entomol 50: 76-79.

9. Gomes L, Gomes G, Oliveira HG, de Carvalho QMM, Von ZCJ (2008) Post-feeding larval dispersal in blowflies during summer and winter seasons in southeast Brazil. Acta Entomologica Sinica 51: 1099-1128.

10. Gomes L, Gomes G, Von ZCJ (2009) The influence of temperature on the behavior of burrowing in larvae of the blowflies, Chrysomya albiceps and Lucilia cuprina, under controlled conditions. J Insect Sci 9: 14.

11. Wigglesworth VB (1965) The principles of insect physiology. Methuen publishers, London, New York.

12. Archer MS, Elgar MA (2003) Effects of decomposition on carcass attendance in a guild of carrion-breeding flies. Med Vet Entomol 17: 263-271.
13. Sukontason K, Piangjai S, Siriwattanarungsee S, Sukontason KL (2008) Morphology and developmental rate of blowflies Chrysomya megacephala and Chrysomya rufifacies in Thailand: application in forensic entomology. Parasitol Res 102: 1207-1216.

14. Charabidzé D, Bourel B, Gosset D (2011) Larval-mass effect: characterisation of heat emission by necrophageous blowflies (Diptera: Calliphoridae) larval aggregates. Forensic Sci Int 211: 61-66.

15. Rivers DB, Ciarlo T, Spelman M, Brogan R (2010) Changes in development and heat shock protein expression in two species of flies (Sarcophaga bullata [Diptera: Sarcophagidae] and Protophormia terraenovae [Diptera: Calliphoridae]) reared in different sized maggot masses. J Med Entomol 47: 677-689.

16. Rivers DB, Thompson C, Brogan R (2011) Physiological trade-offs of forming maggot masses by necrophagous flies on vertebrate carrion. Bull Entomol Res 101: 599-611.

17. Campobasso CP, Di Vella G, Introna F (2001) Factors affecting decomposition and Diptera colonization. Forensic Sci Int 120: 18-27.

18. Clark MA, Worrell MB, Pless JE (1997) Postmortem changes in soft tissues. Forensic taphonomy: the postmortem fate of human remains. CRC press, Florida, USA pp: 151-164.

19. Nielsen BO, Nielsen SA (1976) (Calliphoridae) and vacuum packed ham. Indicators for pest, plant protection. Environmental protection 49: 113-115.

20. Nafte M (2000) Flesh and Bone: An introduction to forensic anthropology. Carolina Academic Press, Durham, NC, USA.

21. Myskowiak JB, Doums C (2002) Effects of refrigeration on the biometry and development of Protophormia terraenovae (Robineau-Desvoidy) (Diptera: Calliphoridae) and its consequences in estimating post-mortem interval in forensic investigations. Forensic Sci Int 125: 254-261.

22. Howe RW (1967) Temperature effects on embryonic development in insects. Annu Rev Entomol 12: 15-42.

23. White RS, Aubertin D, Smart J (1940) The fauna of British India, including remainder of the oriental region: Diptera VI, Family Calliphoridae. Taylor and Francis, London, UK.

24. Grassberger M, Reiter C (2001) Effect of temperature on Lucilia sericata (Diptera: Calliphoridae) development with special reference to the isomegalen-and isomorphen-diagram. Forensic Sci Int 120: 32-36.

25. Abd-AlGalil FM, Zambare SP (2015) Effects of temperature on the development of Calliphorid fly of forensic importance Chrysomya megacephala (Fabricius, 1794). Indian J Appl Res 5: 767-769.

26. Abd-AlGalil FM, Zambare SP (2015a) Effect of temperature on the development of Calliphorid Fly of forensic importance, Chrysomya rufifacies (Macquart, 1842). IJAR 3: 1099-1103.

27. Nabity PD, Higley LG, Heng-Moss TM (2006) Effects of temperature on development of Phormia regina (Diptera: Calliphoridae) and use of developmental data in determining time intervals in forensic entomology. J Med Entomol 43: 1276-1286.

28. Warren JA, Anderson GS (2013) Effect of fluctuating temperatures on the development of a forensically important blow fly, Protophormia terraenovae (Diptera: Calliphoridae). Environ Entomol 42: 167-172.

29. Al-Misned FA, Amoudi MA, Abou-Fannah SS (2003) Development rate, mortality and growth rate of immature Chrysomya albiceps (Wiedemann) (Diptera: Calliphoridae) at constant laboratory temperatures. Journal of King Saud University Science 15: 49-58.

30. Greenberg B (1991) Flies as forensic indicators. J Med Entomol 28: 565-577. 